\title{
LOUISIANA CIVIL CODE JAKO POMOC W USTALANIU I WERYFIKACJI EKWIWALENCJI TERMINOLOGICZNYCH DLA CELÓW TRANSLACYJNYCH I LEKSYKOGRAFICZNYCH
}

\author{
Lukasz ILUK, dr \\ Wyższa Szkoła Finansów i Prawa w Bielsku-Białej \\ ul. Kopernika 97, 34-300 Żywiec \\ lukasz@iluk.katowice.pl
}

\begin{abstract}
Abstrakt: Artykuł pokazuje, co z prawniczego punktu widzenia, jest wartością nadrzędną w translacie: wierność czy komunikatywność. Autor przedstawia motywy stosowania tłumaczenia dosłownego tekstów prawnych oraz skutki jego merytorycznie nieuzasadnionego stosowania. Wychodząc od znaczenia anglojęzycznych kodyfikacji napoleońskich pokazuje się proces poszukiwania i ustalania terminów ekwiwalentnych funkcjonalnie w polskim kodeksie cywilnym i kodeksie cywilnym Luizjany na przykładzie pola terminologicznego: drobne nakłady, nakłady konieczne, inne nakłady i naprawy konieczne. Z przeprowadzonej analizy wynika, że warunkiem znalezienia adekwatnego ekwiwalentu jest dokonanie porównania prawniczego.
\end{abstract}

Słowa klucze: kodeks cywilny Luizjany, terminologia cywilnoprawna, translacja tekstów prawnych, ekwiwalencja funkcjonalna

\section{LOUISIANA CIVIL CODE AS A MEANS OF ESTABLISHING AND VERIFICATION OF TERMINOLOGICAL EQUIVALENCE FOR TRANSLATION AND LEXICOGRAPHY PURPOSES}

\begin{abstract}
The following article shows what from a legal point of view appears as more important in a translated term; either its fidelity or message. It includes reasons for literal translation of legal texts and the consequences of its unjustified use. Starting with the meaning of the Napoleonic codifications in English there appears a process of identifying and establishing functionally equivalent terms in the Polish civil code and the Louisiana civil code exemplified by the terminological field: drobne nakłady, nakłady konieczne, inne nakłady and naprawy konieczne. The analysis indicates that the legal comparison enables finding the right equivalent.
\end{abstract}

Keywords: Louisiana Civil Code, legal terminology, translation of legal texts, functional equivalence 


\section{Wstęp}

Artykuł ma na celu pokazanie, co z prawniczego punktu widzenia, jest wartością nadrzędną w translacie: wierność czy komunikatywność. O ile strategia thumaczenia dosłownego, której efektem jest wierność, nie wymaga wnikliwszych analiz, to strategia przekładu funkcjonalnego, która ukierunkowana jest na komunikatywność, musi opierać się na poszukiwaniu i ustalaniu ekwiwalencji w docelowym systemie prawnym. Aby porównanie systemów prawnych było efektywne i sensowne, należy posługiwać się aktami normatywnymi, które pełnią podobne funkcje i koncentrują się na podobnej materii. Takie przesłanki spełniają kodeks cywilny Luizjany z 1808 r. (LCC) i polski kodeks cywilny z 1964 r. (Kc). W przypadku tłumaczenia na język angielski lub z języka angielskiego podstawową trudność stanowi fakt, że system anglosaski oparty jest na common law, czyli systemie innym niż system w pozostałej części Europy. Nie oznacza to jednak, że nie ma możliwości porównania instytucji prawa, a co za tym idzie terminologii. Istnieją bowiem systemy prawa, w których common law i system prawa stanowionego funkcjonują obok siebie jako podsystemy systemu mieszanego. $\mathrm{Z}$ uwagi na powyższe, w niniejszym artykule przedstawiony zostanie proces poszukiwania i ustalania terminów ekwiwalentnych funkcjonalnie w różnych systemach prawnych.

\section{Motywy stosowania tlumaczenia dosłownego tekstów prawnych}

Przekonanie o konieczności zachowania litery prawa, zdaniem Kielar (2010: 139), narzuca thumaczowi rygor zachowania wierności w stosunku do tekstu źródłowego w najwyższym stopniu i przyjęcie tłumaczenia dosłownego jako złotej reguły. Przeświadczenie to wzmacniają obligatoryjna forma, a przede wszystkim funkcje tekstu prawnego. Również pozorna możliwość semantyzacji nazw prawnych na podstawie ich struktury leksykalno-semantycznej motywuje tłumacza do kalkowania wzorów semantycznych terminów języka wyjściowego. Skłonność do stosowania przekładu dosłownego cechuje - zdaniem Pieńkosa (2003: 275) - zwłaszcza tych tłumaczy, którzy, nie dysponując odpowiednią wiedzą na temat dziedziny, której tekst dotyczy, z obawy przed popełnieniem nieścisłości trzymają się kurczowo tekstu oryginalnego, kalkując terminy prawne, ich struktury znaczeniowe lub motywy nazwotwórcze. Stosując 
formalne zasady przekładu, tłumacz interpretuje terminy głównie na podstawie motywów nazwotwórczych $\mathrm{i}$ ich wzajemnych relacji, natomiast prawnik przypisuje im cechy pojęciowe, które nadał normotwórca, a które są niewidoczne w ich powierzchniowej strukturze. Zatem bez odpowiedniej wiedzy thumacz skazany jest na naśladowanie cech powierzchniowych terminów z wyjściowego systemu prawnego.

Inni specjaliści traduktologii, jak np. Kierzkowska (2002: 59) lub Pommer (2006: 51), podzielając argumentację Šarčević (1990: 157), twierdzą, że w przypadku ekwiwalencji funkcjonalnej istnieje niebezpieczeństwo przypisywania użytym $\mathrm{w}$ translacie terminom znaczeń $\mathrm{z}$ docelowego systemu prawnego, co przy istniejących różnicach systemowych może prowadzić do wyciągania niewłaściwych wniosków prawnych. Temu niebezpieczeństwu ma zapobiegać taki przekład, który już na poziomie terminologicznym sygnalizuje, że nie jest tłumaczeniem ukrytym. Podobne stanowisko reprezentują autorzy Kodeksu tłumacza przysięglego z komentarzem (Kierzkowska 2005: 90-92), którzy zalecają, by w przypadku nieprzystawalnych systemów prawnych stosować ekwiwalencję formalną, dokładnie odzwierciedlającą realia obszaru kulturowego języka źródłowego.

W przekonaniu autora, preferencja tłumaczenia według zasad formalnych może również wynikać nie tylko z braku odpowiedniej wiedzy specjalistycznej o docelowym systemie prawnym, lecz także $\mathrm{z}$ procedury weryfikacji poprawności thumaczenia poprzez jego retranslację. Tłumaczenie formalne spełnia ten wymóg, natomiast funkcjonalne nie. Skoro tak jest, to w przekładzie prawniczym należy preferować przekład dosłowny. Taki uzus do niedawna obowiązywał w Szwajcarii, gdzie obowiązujący system prawny formułowany jest w trzech językach. Dosłowne thumaczenie aktów normatywnych w tym kraju wywoływało zrozumiałą krytykę prawników (Šarčević 1997: 37-8).

\section{Skutki merytorycznie nieuzasadnionego stosowania tłumaczenia dosłownego (imitacyjnego)}

Wymóg precyzji terminologicznej jest zdaniem Šarčević (1990: 157) warunkiem sine qua non poprawności thumaczenia tekstów prawniczych. Analizując jakość tłumaczeń traktatów akcesyjnych UE oraz przekładu polskiej konstytucji na język angielski Kielar (2010: 132) zauważyła, że nieuwzględnianie specyfiki języka prawnego skutkuje często tym, że: 
tlumacze wchodza na bezdroża przypadkowych wyborów środków językowych, nie nawiazujacych do myśli translatorycznej i prawniczej $i-$ nie zważajac na cel komunikacji - produkuja ciagi wyrazów, które albo zniekształcają komunikat źródtowy, albo sq całkowicie pozbawione sensu.

Do nich zalicza przekład dosłowny, wprowadzanie faux amis i kalkowanie struktur zdaniowych (Kielar 2010: 144). Według de Groota (1990: 123) tłumaczenie dosłowne wymusza stosowanie terminów potocznych, które naruszają normy preskryptywne w języku docelowym. Jest to zatem ważny argument przeciw merytorycznie nieuzasadnionemu stosowaniu tłumaczenia opartego na ekwiwalencji formalnej. Według Pieńkosa (2003: 136) zasadę dosłowności powinno się stosować tylko w przypadku takich tekstów, które pozwalają na jej zastosowanie, czyli nazw np. instytucji, organów administracyjnych, sądów, uczelni, organizacji społecznych, przedsiębiorstw itp. Drugim warunkiem stosowania tej zasady jest - jego zdaniem - niekolidowanie znaczeń. Ze względu na różnorodność tekstów i ryzyko zakłócenia przekazu lub zrozumienia w ogóle Pieńkos (2003: 137) przestrzega przed nadmiernym posługiwaniem się ekwiwalencją formalną.

W związku z powyższym Kielar (2007: 31) zaleca szersze uwzględnianie relewantnych czynników komunikacyjnych, narzucających sposób rozwiązania kwestii translacyjnych. Jej zdaniem na pierwszy plan wysuwa się czynnik zwany efektem prawnym, który powinien być zachowany również w translacie (Kielar 2010: 138). W określonych przypadkach efekt ten nie jest możliwy do uzyskania przez reprodukowanie oryginalnego tekstu za pomocą literalnych odpowiedników w języku docelowym, ponieważ - jak przestrzega Pieńkos (1999: 127) - takie postępowanie może powodować niezrozumiałość translatu lub nawet wypaczenie sensu prawnego, co z kolei może pociągać za sobą niepożądane $\mathrm{z}$ punktu widzenia prawnej zasady legalizmu skutki prawne. Dotyczy to $\mathrm{w}$ szczególności terminologicznie niepoprawnych przekładów na potrzeby postępowań sądowych lub administracyjnych, które mogą wprowadzić w błąd organ stosujący prawo, powodując błędne zakwalifikowanie instytucji prawa.

\section{Tłumaczenie funkcjonalne na płaszczyźnie terminologicznej}

Podstawowym elementem każdego tekstu specjalistycznego jest swoiste słownictwo, którego główny trzon stanowią terminy. Skoro dosłowny przekład 
terminologii prawnej nie zawsze gwarantuje jej poprawność w tekście docelowym i tym samym przyczynia się w znacznym stopniu do niezrozumienia lub nieprecyzyjnego zrozumienia treści translatu, to kwestie znalezienia optymalnego ekwiwalentu terminologicznego nabierają szczególnej rangi, na co już pół wieku temu zwrócił uwagę Catford (1965: 21):

The central problem of translation-practice is that of finding $T L$ translation equivalents. A central task of translation theory is that of defining the nature and conditions of translation equivalence.

Na wybór strategii poszukiwania ekwiwalentu w tekście docelowym ma wpływ niewątpliwie typ ekwiwalencji terminologicznej. Zgodnie z Pieńkosem (1999: 124) terminy można podzielić w następujący sposób:

- terminy, które mają swoje odpowiedniki semantyczne i najczęściej wywodzą się z prawa rzymskiego, prawa europejskiego lub międzynarodowego ${ }^{1}$;

- terminy, które nie mają swojego dokładnego ekwiwalentu, ale dla których można znaleźć ekwiwalent funkcjonalny;

- terminy, które są nieprzekładalne.

Wyróżnione powyżej kategorie mają kluczowy wpływ na wybór strategii przekładu. Terminy, które mają swoje odpowiedniki semantyczne, są preferowane $\mathrm{w}$ thumaczeniu dosłownym zorientowanym na wyrazach (wordoriented translation). Można je bez większego trudu znaleźć w dwujęzycznych słownikach. Druga kategoria terminów (nie mająca bezpośrednich odpowiedników semantycznych $\mathrm{w}$ docelowym systemie prawnym) wymaga stosowania ekwiwalencji funkcjonalnej. Trzecia kategoria przekładana jest za pomocą różnych strategii translacyjnych. ${ }^{2}$

Ze względu na ramy artykułu w dalszej jego części zajmiemy się kwestią ustalania ekwiwalencji funkcjonalnej. Weston (1991: 21) uważa, że "the technique of using a functional equivalent may be regarded as the ideal method of translation". W przypadku przekładu tekstów prawniczych ekwiwalencja funkcjonalna odwołuje się do analogicznej instytucji w systemie prawa docelowego, wykorzystując pojęcia o zbliżonej funkcji. Šarčević (1997: 236)

\footnotetext{
${ }^{1}$ Powyższy podział wydaje się uzasadniony, choć nie pełny. Jeżeli w pierwszym przypadku odrębną kategorię stanowią terminy pochodzące $\mathrm{z}$ prawa rzymskiego, jako konkretnej i istotnej kultury prawnej; prawa europejskiego i międzynarodowego, których stanowienie (a właściwie współstanowienie) determinuje jednolitą terminologię, to wydaje się, że do tej kategorii należy włączyć także terminologię, która pochodzi z kodyfikacji napoleońskich w tym zakresie, w jakim nie czerpała ona z tradycji rzymskich, a wiadomo, że inspirację tymi kodyfikacjami, czy wręcz ich naśladownictwo obejmowało szerokie kręgi.

${ }^{2}$ Katalog strategii przekładu terminologii bezekwiwalentnej w oparciu o literaturę przedmiotu podaje Matulewska (2005: 65).
} 
definiuje pojęcie ekwiwalencji funkcjonalnej jako "a term designating a concept or institution of the target legal system having the same function as a particular concept of the source legal system". Odwoływanie się do analogicznej instytucji w systemie prawa docelowego wymaga odnalezienie jej w docelowym systemie prawnym. Zdaniem Šarčević (1997: 237) włączenie porównania prawa do procesu przekładu jest niezbędnym krokiem w procesie tłumaczenia i dlatego zaleca thumaczom ,they should be assisted by [...] lawyer linguists who are able to conduct comparative law studies". Również de Groot (2000: 133) uważa, że tłumaczenie terminologii prawnej wymaga porównania prawa, co potwierdza poniższy cytat:

Translators of legal terminology are obliged to practice comparative law. Through comparative law, the translator of legal terminology needs to find an equivalent in the target legal system for the term of the source language system.

Zdaniem Boquect'a (1994 za: Pommer 2006: 35) faza poszukiwania ekwiwalentu terminologicznego $\mathrm{w}$ systemie prawa docelowego ma charakter czysto prawnoporównawczy. Polega ono na tym, że porównuje się instytucje wyjściowego systemu prawnego z instytucjami prawnymi systemu docelowego. Podobny pogląd w tej sprawie reprezentują Pieńkos (2003: 106) i Zieliński (2005: 39). Ich zdaniem poszukiwanie odpowiednika terminologicznego musi opierać się na porównaniu systemów prawnych i stosownych siatek pojęć. Šarčević (1997: 235236) stawia tezę, że interlingwalne ekwiwalenty funkcjonalne nie muszą wykazywać ekwiwalencji pojęciowej. W takiej sytuacji zaleca ona, aby, poszukując ekwiwalentnych pojęć prawnych, posługiwać się metodologią prawną:

Similarly, when searching for equivalents in the target legal system, translators should approach the matter as if they were solving a legal problem. Like the judge, they should identify the nature of the issue at hand and determine how that issue is dealt with in the target legal system. This should lead the translator to the concept or institution in the target legal system that has the same function as the concept concerned in the source legal system.

W tym kontekście Pommer (2006: 146) podkreśla, że wiedza tłumacza nie powinna obejmować wyłącznie wiedzy o systemach prawnych, lecz także o prawnych technikach interpretacyjnych, ponieważ wykładnia prawa pokazuje, w jaki sposób prawnik ustala znaczenie prawa. Do konieczności stosowania 
wykładni prawa w określonych sytuacjach zmusza wręcz sam ustawodawca. Na przykład w art. 12 kodeksu Luizjany, odnoszącym się do niejednoznaczności terminów prawnych, postanowiono, że ,When the words of a law are ambiguous, their meaning must be sought by examining the context in which they occur and the text of the law as a whole". W praktyce oznacza to konieczność dokonywania wykładni prawa, czyli ustalania znaczenia i zakresu pojęć.

Porównanie takie ,powinno prowadzić do wskazania odpowiedniego terminu, pojęcia albo instytucji w języku docelowym, których funkcja będzie taka sama lub podobna, jak w tekście źródłowym (ekwiwalent funkcjonalny) (Pieńkos 2003: 110). Ustalenie zakresu pokrywania się znaczeń, tj. istniejących podobieństw i różnic, między potencjalnymi parami terminologicznymi w języku prawa wymaga szczegółowej analizy pojęciowej (de Groot 1990: 124; Pieńkos 2003: 106; Schmidt-König 2005: 108). Zdaniem Kielar (2007: 30):

Tłumacz nie powinien [...] mechanicznie podstawiać terminów wyjętych zjęzyka docelowego, oznaczajacych podobne instytucje prawne, ale musi badać stopień ich ekwiwalencji funkcjonalnej i/lub formalnej. Ma przy tym szukać podobieństw instytucjonalnych, ale zarazem nie utożsamiać ze soba rzeczy niewystarczajaco podobnych.

Poszukując ekwiwalentnych terminów w docelowym języku prawnym, „tłumacz musi nieustannie uruchamiać swoją wiedzę o regulowanej prawem dziedzinie (czyli wiedzę „dziedzinową", „merytoryczną”) oraz wiedzę prawną i prawniczą, aby negocjować znaczenia uwzględniając zakres wspólnej wiedzy o świecie i odpowiedniej wiedzy prawnej i prawniczej przewidywanych odbiorców" (Kielar, Wiedza, 2007: 29). Zgodnie z zacytowaną myślą, poszukiwanie odpowiednika terminologicznego polega na znalezieniu w systemie prawa docelowego pojęcia, które jest ekwiwalentnie zdefiniowane jak w systemie wyjściowym. Na podstawie definicji można zatem ustalić zakresy pokrywania się pojęć i znaczeń w przyporządkowanym im nazwom. Efektywność tego poszukiwania uzależniona jest zatem od merytorycznej wiedzy prawnej, której tłumacz z natury rzeczy nie posiada.

Niemniej w wielu przypadkach ekwiwalencji funkcjonalnej nie da się ustalić ze względu na nieprzystawalność systemów prawnych lub kultury prawnej. Takie sytuacje zwykle skłaniają translatorów do tłumaczenia literalnego lub tworzenia neologizmów. Wydaje się jednak, że takie postępowanie powinno być ostatecznością. Niektórzy specjaliści, jak np. de Groot (1999: 33), Pieńkos (2003: 173) lub Matulewska (2005: 66) radzą, by rozważać możliwość poszukiwania ekwiwalentu funkcjonalnego $\mathrm{w}$ innym systemie prawnym, który wykorzystuje ten sam język docelowy. 
Strategia ta, jak podaje de Groot (1999: 33), została usankcjonowana nawet $\mathrm{w}$ przepisach brytyjskich, a konkretnie $\mathrm{w}$ art. 16, punkt 1 Jurysdykcji uznawania orzeczeń sadowych oraz ich wykonywanie $w$ sprawach cywilnych i handlowych (,,Bruksela I"), gdzie w przypadku braku akceptowalnego ekwiwalentu w brytyjskim systemie prawnym dla terminu droit réel posłużono się terminem z prawa rzymskiego:

The following courts shall have exclusive jurisdiction, regardless of domicile: 1. on proceedings which have as their object rights in rem ....

Posługiwanie się terminem $\mathrm{z}$ innego systemu prawnego, który używa tego samego języka docelowego, powinno zawsze mieć na celu precyzję przekładu pojęcia prawnego. W przypadku tłumaczenia terminologii prawa polskiego na język angielski można się posłużyć ekwiwalentną terminologią anglojęzyczną zawartą w tych systemach prawnych, które bazują, podobnie jak prawo polskie, na kodeksie napoleońskim lub wręcz są jego translatami. Na przykład kodeks cywilny obowiązujący w Quebeku w wersji anglojęzycznej zawiera terminologię inspirowaną językiem francuskim (de Groot 2002: 227). Innym źródłem konsultacyjnym może być kodeks cywilny obowiązujący w stanie Luizjany w USA. Za jego szerszym wykorzystaniem jako bazy terminologicznej i frazeologicznej podczas przekładu polskich tekstów prawnych na język angielski opowiada się w zdecydowany sposób Matulewska (2005: 66). Jej analiza wybranych terminów prawnych potwierdziła przydatność anglojęzycznej terminologii Louisiana Civil Code dla celów translacyjnych.

\section{Znaczenie anglojęzycznych kodyfikacji napoleońskiej dla celów translacyjnych}

Zdaniem wybitnego historyka prawa, Michała Sczanieckiego, kodeks cywilny Francuzów należy ocenić jako ,,pierwszy na świecie wzorowy kodeks prawa cywilnego epoki kapitalizmu" (1997: 359). Sczaniecki stwierdza nawet, że kodeks ten „oceniany jest powszechnie jako arcydzieło techniki ustawodawczej. Jego zwięzłość i jasność oraz piękny język stawiają go w rzędzie najlepszych kodyfikacji w dziejach ludzkości" (Sczaniecki 1997: 360). Nie powinien zatem dziwić fakt, że wielka kodyfikacja francuska wywarła ogromny wpływ na rozwój prawa, także poza granicami Francji. Dużą popularnością cieszył się kodeks cywilny. Wprowadzony na większości terenów „Wielkiego Cesarstwa”, utrzymał się on w niektórych z nich nawet po upadku Napoleona. W pruskiej Nadrenii 
oraz w Badenii obowiązywał do roku 1900 pod nazwą Landrechtu Badeńskiego. W Belgii obowiązuje on po dzień dzisiejszy. Na kodeksie cywilnym oparły się kodeksy: włoski z roku 1865, hiszpański, portugalski - a poza Europą - kodeks w kanadyjskim Quebeku. Kodeks przygotowywany przez Fielda dla Nowego Jorku został ostatecznie wprowadzony tylko do stanów Kalifornii i Dakoty. Podobnie dotarł on i do Luizjany (Sczaniecki 1997: 362).

Kodyfikacja napoleońska prawa cywilnego nie ominęła także Polski. Kodeks wprowadzony np. w Księstwie Warszawskim obowiązywał - z pewnymi zmianami - na ziemiach polskich do roku 1933 w materii zobowiązań, a do roku 1946 w innych działach (Sczaniecki 1997: 362). Okazuje się, że niektóre regulacje kodeksu napoleońskiego mogą obowiązywać w Polsce nawet dzisiaj. Potwierdza to wydana w 2013 r. uchwała Sądu Najwyższego, w której stwierdzono, że przepis art. 713 Kodeksu Napoleona może stanowić samoistną podstawę wpisu do księgi wieczystej własności nieruchomości. ${ }^{3}$

Powyższe zależności sprawiają, że w poszczególnych systemach prawnych lub $\mathrm{w}$ zakresie poszczególnych dziedzin prawa, które czerpały z kodyfikacji napoleońskiej, da się wyraźnie zauważyć jej wpływ na rozwój kultury prawnej w danym kraju. Mimo że w większości państw kodeks Napoleona został zastąpiony nowszymi aktami normatywnymi, widać, że współczesne regulacje nadal czerpią z kodyfikacji napoleońskich. Taki stan rzeczy sprzyja porównaniu norm prawnych. To samo dotyczy terminologii. Różnice w nazewnictwie są na ogół wynikiem późniejszych zabiegów legislacyjnych, wynikających ze zmieniającej się rzeczywistości społecznogospodarczej. Wszystko to sprawia, że akty normatywne powstałe na bazie kodeksu Napoleona idealnie nadają się do prowadzenia komparatystyki dla celów translacyjnych, zwłaszcza że prawo stanowione funkcjonujące obok common law w tym samym państwie lub stanie jest okolicznością rzadko spotykaną.

\section{Przykłady poszukiwania anglojęzycznych ekwiwalentów funkcjonalnych w LCC na bazie porównania prawniczego}

Dla egzemplifikacji metody porównania prawniczego dla celów translacyjnych posłużymy się celowo wybranymi terminem prawnymi: drobne nakłady, nakłady konieczne, inne nakłady i naprawy konieczne. Należy zwrócić uwagę, że ww.

\footnotetext{
${ }^{3}$ Sygnatura akt III CZP 29/13, uchwała z 27 czerwca 2013 r.
} 
terminy tworzą pole terminologiczne, którego wspólnym elementem jest pojęcie 'nakład', względnie naprawa rozumiana jako nakład. ${ }^{4}$

Problem precyzyjnego przekładu tych terminów wynika po pierwsze z faktu, że nawet doświadczony tłumacz może nie zidentyfikować tych wyrażeń językowych jako terminów prawa, ponieważ leksykalne składniki tych nazw są wyrazami języka potocznego. ${ }^{5}$ Dlatego łatwo można ulec złudzeniu, że terminy te są w pełni zrozumiałe, a ich konstrukcja formalna i znaczeniowa jest na tyle transparentna, że może zostać przekodowana na język docelowy z zachowaniem ekwiwalencji formalnej. Podczas gdy laik wyrażenie drobne nakłady rozumie jako „niewielkie koszty”, prawnik odnosi ten termin do wiedzy na temat konkretnego stosunku prawnego, czyli jego podmiotu, przedmiotu i treści stosunku, z których wynika, kto i w jakich okolicznościach jest zobowiązany do ich dokonywania. W przeciwieństwie do tłumacza prawnik, mając do czynienia $\mathrm{z}$ badaną nazwą, natychmiast identyfikuje ją nie tylko jako termin prawny, ale od razu kwalifikuje go jako nazwę pojęcia $\mathrm{z}$ określonego działu prawa, a nawet wiąże go z konkretnymi przepisami. Dokonuje więc swojego rodzaju systematyki w oparciu o posiadaną wiedzę.

Tymczasem w powierzchniowej strukturze nazwy drobne nakłady nie ma żadnych odniesień do konstytutywnych cech oznaczanego pojęcia. Po drugie, termin drobne nakłady należy uznać za nazwą zagregowaną, składającą się z kilku różnych cech pojęciowych (Hannappel i Melenk 1990: 156). Problematyka nazw zagregowanych polega na tym, że ich zawartość semantyczna nie jest dla laika widoczna w powierzchniowej strukturze nazwy, dlatego thumacz nie jest $\mathrm{w}$ stanie ustalić tych cech pojęciowych, które są kluczowe do ustalenia ekwiwalencji. Tymi niewidocznymi cechami w analizowanym przypadku są okoliczności i podmiot obciążony drobnymi nakładami.

Rozumienie prawnego kontekstu pojęcia drobne nakłady wymaga bardziej szczegółowej eksplikacji. Jest ono pojęciem prawa cywilnego, którego podstawowym źródłem jest kodeks cywilny. Polski ustawodawca celowo wprowadził pojęcie drobne nakłady, aby odróżnić je od napraw koniecznych i w nieco szerszym kontekście także od nakładów koniecznych oraz innych nakładów. W każdym z tych przypadków chodzi o dokonywanie określonych napraw (względnie inwestycji), które obciążają konkretny podmiot. Drobne nakłady i naprawy konieczne są pojęciami działu najmu w kodeksie cywilnym, natomiast nakłady konieczne są także pojęciem prawa cywilnego, jednak nie

\footnotetext{
${ }^{4}$ Więcej na temat pól terminologicznych zob. Iluk, Łukasz. 2014. Pole terminologiczne jako instrument konfrontacji leksyki prawnej. W Studia Translatorica 5. Wrocław-Dresden.

${ }^{5}$ Brak tych haseł w polsko-angielskich słownikach prawniczych może dowodzić, że ich autorzy nie zidentyfikowali ww. nazw jako terminów prawnych. 
muszą być bezpośrednio związane z najmem. Wynika to z tego, że te instytucje prawa stosuje się w prawnych stosunkach posiadania, czyli zarządu nad rzeczą, która nie stanowi własności podmiotu, który faktycznie daną rzeczą włada jak właściciel (posiadacz samoistny) ${ }^{6}$. Rzecz jasna najem też jest tego rodzaju stosunkiem prawnym, tym niemniej $w$ przepisach o najmie ustawodawca odróżnia dodatkowo naprawy konieczne, uregulowane w art. $663 \mathrm{Kc}$ (dział: najem) od nakładów koniecznych, uregulowanych w art. $226 \mathrm{Kc}$ (dział: ochrona własności). Wymienione powyżej instytucje prawa występują także w kodeksie Luizjany. Spróbujemy je teraz ze sobą porównać, by ustalić ich konstytutywne cechy pojęciowe. Dla lepszej orientacji zostaną one zestawione obok siebie.

Przykład I: naprawy konieczne

Kwestie napraw koniecznych regulują w obu systemach prawnych następujące przepisy:

Art. 663 Kc, Naprawy konieczne

Jeżeli $w$ czasie trwania najmu rzecz wymaga napraw, które obciażaja wynajmujacego, a bez których rzecz nie jest przydatna do umówionego użytku, najemca może wyznaczyć wynajmujacemu odpowiedni termin do wykonania napraw. Po bezskutecznym uplywie wyznaczonego terminu najemca może dokonać koniecznych napraw na koszt wynajmującego.

Art. $662 \mathrm{Kc} \S 1$. Wynajmujacy powinien wydać najemcy rzecz $w$ stanie przydatnym do umówionego użytku i utrzymywać ja w takim stanie przez czas trwania najmu. [...].

Art. 2691 LCC, Lessor's obligation for repairs

During the lease, the lessor is bound to make all repairs that become necessary to maintain the thing in a condition suitable for the purpose for which it was leased, except those for which the lessee is responsible.

Art. 2694 LCC, Lessee's right to make repairs

If the lessor fails to perform his obligation to make necessary repairs within a reasonable time after demand by the lessee, the lessee may cause them to be made. The lessee may demand immediate reimbursement of the amount expended for the repair or apply that amount to the payment of

\footnotetext{
${ }^{6}$ Por. art. 336 Kc: Posiadaczem rzeczy jest zarówno ten, kto nią faktycznie włada jak właściciel (posiadacz samoistny), jak i ten, kto nią faktycznie włada jak użytkownik, zastawnik, najemca, dzierżawca lub mający inne prawo, z którym łączy się określone władztwo nad cudzą rzeczą (posiadacz zależny).
} 
rent, but only to the extent that the repair was necessary and the expended amount was reasonable.

Jak wynika z zacytowanych regulacji w polskim systemie prawnym instytucja napraw koniecznych została usystematyzowana $\mathrm{w}$ jednym przepisie, $\mathrm{w}$ którym ustawodawca nakłada obowiązek utrzymania rzeczy na wynajmującego, ale jednocześnie zastrzega prawo najemcy do dokonania napraw koniecznych i do żądania poczynionych nakładów od wynajmującego. Jednak materię napraw koniecznych (art. $663 \mathrm{Kc}$ ) należy interpretować w kontekście art. $662 \S 1 \mathrm{Kc}$, ponieważ treść art. $663 \mathrm{Kc}$ stanowi rozwinięcie obowiązku wynajmującego przewidzianego $\mathrm{w}$ art. $662 \S 1 \mathrm{Kc}$.

W kodeksie cywilnym Luizjany materia napraw koniecznych została uregulowana $\mathrm{w}$ dwóch przepisach, które osobno regulują obowiązek wynajmującego i osobno prawo najemcy. Sama systematyka przepisów nie ma żadnego znaczenia z punktu widzenia ustalania cech pojęć. Konstytutywne cechy analizowanego pojęcia prawnego przedstawia poniższe zestawienie.

\begin{tabular}{|l|l|}
\hline $\begin{array}{c}\text { Cechy konstytutywne terminu naprawy } \\
\text { konieczne }\end{array}$ & \multicolumn{1}{|c|}{ Ekwiwalentne cechy w LCC } \\
\hline naprawy obciążają wynajmującego & the lessor is bound to make repairs \\
\hline $\begin{array}{l}\text { rzecz w stanie przydatnym do } \\
\text { umówionego użytku i utrzymywać ją w } \\
\text { takim stanie }\end{array}$ & $\begin{array}{l}\text { maintain the thing in a condition } \\
\text { suitable for the purpose (lease) }\end{array}$ \\
\hline $\begin{array}{l}\text { najemca może dokonać koniecznych } \\
\text { napraw na koszt wynajmującego }\end{array}$ & $\begin{array}{l}\text { lessee may cause them to be made, } \\
\text { lessee may demand immediate } \\
\text { reimbursement for the repair, repair } \\
\text { was necessary }\end{array}$ \\
\hline
\end{tabular}

Zestawienie to potwierdza pełne pokrywanie się zakresów pojęciowych. Zatem można przyjąć, że anglojęzyczna nazwa necessary repairs, reprezentująca te cechy, jest pełnym ekwiwalentem polskiego terminu naprawy konieczne. Ponadto posiada tożsame motywy nazwotwórcze oraz podobny sposób zespolenia składników, co pozwala na zastosowanie tłumaczenia dosłownego. ${ }^{7}$

Przykład II: nakłady - nakłady konieczne, inne nakłady

\footnotetext{
${ }^{7}$ Więcej na temat zakresów ekwiwalencji między terminami z dwóch systemów prawnych w J. Iluk (2012). 
Kwestie nakładów, nakładów koniecznych i innych nakładów regulują w obu systemach prawnych następujące przepisy:

\section{A. nakłady konieczne}

Art. 226 Kc, Naktady

$\S$ 1. Samoistny posiadacz $w$ dobrej wierze może żąać zwrotu nakładów koniecznych o tyle, o ile nie maja pokrycia $w$ korzyściach, które uzyskat z rzeczy. Zwrotu innych nakładów może żadać o tyle, o ile zwiększaja wartość rzeczy w chwili jej wydania właścicielowi. [...].

\section{Art. 527 LCC, Necessary expenses}

The evicted possessor, whether in good or in bad faith, is entitled to recover from the owner compensation for necessary expenses incurred for the preservation of the thing and for the discharge of private or public burdens. [...].

\section{Art. 528 LCC, Useful expenses}

An evicted possessor in good faith is entitled to recover from the owner his useful expenses to the extent that they have enhanced the value of the thing.

Podobnie jak w przypadku napraw koniecznych, w obu systemach przyjęto nieco inną systematykę przepisów o nakładach. Polski ustawodawca uregulował je w jednym przepisie, choć wyraźnie je od siebie odróżniając (nakłady konieczne, inne nakłady), podczas gdy w kodeksie Luizjany materia nakładów została uregulowana $\mathrm{w}$ osobnych przepisach. Porównajmy najpierw konstytutywne cechy analizowanego pojęcia nakładów koniecznych w Kc i LCC.

Konstytutywne cechy analizowanego pojęcia prawnego przedstawia poniższe zestawienie.

\begin{tabular}{|c|c|}
\hline $\begin{array}{c}\text { Cechy konstytutywne terminu } \\
\text { naktady konieczne }\end{array}$ & Ekwiwalentne cechy w LCC \\
\hline samoistny posiadacz w dobrej wierze & evicted possessor in good or in bad faith \\
\hline zwrot nakładów koniecznych & $\begin{array}{l}\text { recover compensation for necessary } \\
\text { expenses }\end{array}$ \\
\hline
\end{tabular}

Powyższe zestawienie potwierdza wysokie podobieństwo cech pojęciowych w obu systemach prawnych, mimo że w kodeksie Luizjany dopuszcza się zwrotu nakładów koniecznych niezależnie od tego, czy samoistny posiadacz działa 
w dobrej czy złej wierze. Różnica ta jest istotna z prawnego punktu widzenia, natomiast $\mathrm{z}$ perspektywy terminologicznej jest irrelewantna. Można zatem uznać, że angielska nazwa necessary expenses, która reprezentuje analizowane pojęcie jest funkcjonalnym ekwiwalentem polskiego terminu nakłady konieczne. Ponadto oba terminy mają identyczne motywy nazwotwórcze i sposób zespolenia składników, dlatego umożliwiają zastosowanie przekładu dosłownego.

B. inne naktady

\begin{tabular}{|l|l|}
\hline $\begin{array}{c}\text { Cechy konstytutywne terminu inne } \\
\text { naktady }\end{array}$ & \multicolumn{1}{c|}{ Ekwiwalentne cechy w LCC } \\
\hline samoistny posiadacz w dobrej wierze & evicted possessor in good faith \\
\hline inne nakłady & (to recover) useful expenses \\
\hline zwiększona wartość rzeczy & enhanced the value of the thing \\
\hline
\end{tabular}

Zestawienie cech pojęciowych uwidacznia, że w obu systemach prawnych ustawodawca rozróżnia dwa rodzaje nakładów: nakłady konieczne i inne nakłady. Ich porównanie pozwala stwierdzić, że w obu systemach prawnych zachodzi tożsamość funkcjonalna tych instytucji prawa. W przypadku instytucji nakładów koniecznych zachodzi również ekwiwalencja motywacyjna. Takiej ekwiwalencji nie ma w przypadku polskiego terminu inne nakłady i jego funkcjonalnego odpowiednika w LCC. Zgodnie z treścią art. 528 LCC należy uznać, że jego odpowiednikiem w systemie prawnym Luizjany jest termin useful expenses, a nie other expenses, ponieważ ten ostatni nie spełnia norm preskryptywnych LCC. Ze względu na odmienne motywy nazwotwórcze w polskiej i anglojęzycznej nazwie wykluczone jest ich tłumaczenie formalne. Warto nadmienić, że z prawnego punku widzenia termin useful expenses jest bardziej precyzyjny niż jego odpowiednik w polskim systemie prawa.

Przykład III: drobne nakłady

Materia drobnych nakładów została uregulowana w następujących przepisach:

Art. 662 Kc, Stan i utrzymanie rzeczy

$\S 1$. Wynajmujacy powinien wydać najemcy rzecz $w$ stanie przydatnym do umówionego użytku i utrzymywać ja $w$ takim stanie przez czas trwania пајти.

§ 2. Drobne nakłady połaczone ze zwykłym używaniem rzeczy obciażaja najemcę. 
§ 3. Jeżeli rzecz najęta uległa zniszczeniu z powodu okoliczności, za które wynajmujacy odpowiedzialności nie ponosi, wynajmujacy nie ma obowiązku przywrócenia stanu poprzedniego.

Art. 681 Kc, Drobne naktady

Do drobnych naktadów, które obciązaja najemcę lokalu, należa w szczególności: drobne naprawy podtóg, drzwi i okien, malowanie ścian, podtóg oraz wewnętrznej strony drzwi wejściowych, jak również drobne naprawy instalacji i urzadzeń technicznych, zapewniajacych korzystanie ze światta, ogrzewania lokalu, doptywu i odplywu wody.

Art. 2692 LCC, Lessee's obligation to make repairs

The lessee is bound to repair damage to the thing caused by his fault or that of persons who, with his consent, are on the premises or use the thing, and to repair any deterioration resulting from his or their use to the extent it exceeds the normal or agreed use of the thing.

W polskim systemie prawnym pojęcie drobne nakłady w rozumieniu art. $662 \S 2$ Kc nie jest zbyt jasne, stąd w art. $681 \mathrm{Kc}$ ustawodawca wskazał przykładowy (niezamknięty) katalog drobnych nakładów. Określił jednocześnie, że drobne naktady należy rozumieć jako „drobne naprawy”. Konstytutywne cechy analizowanego pojęcia prawnego przedstawia poniższe zestawienie.

\begin{tabular}{|l|l|}
\hline \multicolumn{1}{|c|}{$\begin{array}{c}\text { Cechy konstytutywne terminu drobne } \\
\text { naktady }\end{array}$} & \multicolumn{1}{c|}{ Ekwiwalentne cechy w LCC } \\
\hline obciążają najemcę & lessee is bound \\
\hline drobne nakłady, drobne naprawy & (to repair) any deterioration \\
\hline zwykłe używanie rzeczy & $\begin{array}{l}\text { normal (or agreed) use of the } \\
\text { thing }\end{array}$ \\
\hline
\end{tabular}

Zestawione powyżej cechy potwierdzają pokrywanie się zakresów pojęciowych, czyli można mówić tu o pełnej ekwiwalencji pojęciowej. W LCC reprezentuje go nazwa repair of deterioration. Porównując polską nazwę z jej anglojęzycznym odpowiednikiem, można stwierdzić, że różnią się motywami nazwotwórczymi, co wyklucza stosowanie tłumaczenia dosłownego. Co więcej, bez porównania prawa nie jest możliwe precyzyjne ustalenie odpowiednika terminologicznego, spełniającego normy preskryptywne docelowego systemu prawnego. Bazując na strukturze powierzchownej polskiej nazwy i stosując zasady tłumaczenia formalnego uzyskano by efekt $\mathrm{w}$ postaci small repairs. Mając na uwadze powyższe, użycie takiej nazwy nie spełnia norm preskryptywnych w docelowym 
systemie prawnym i - co gorsza - ze względu na brak precyzji prawnej jest niejasne dla adresata translatu.

\section{Wnioski}

Pieńkos (2003: 228), w przekonaniu Autora, stawia słuszną tezę, że zawsze należy dążyć do osiągnięcia maksymalnej ekwiwalencji. Natomiast - jak wskazują specjaliści z zakresu translacji, o czym była mowa wyżej - tłumacze nadużywają przekładu dosłownego. Kielar (2010: 139), konkludując wyniki prowadzonych przez siebie badań, stwierdziła, że nadmierna dążność do zachowania wierności oryginałowi w procesie przekładu okazywała się pozorna i zwodnicza z uwagi na dwufazowość procesu komunikacji z udziałem tłumacza jako pośrednika językowego, kulturowego i komunikacyjnego. Jej zdaniem ograniczona wiedza specjalistyczna wymusza thumaczenie nie ,przez treść”, ale „naśladownictwo cech powierzchownych tekstu j1”. W związku z tym tylko szeroka i dogłębna wiedza specjalistyczna pozwala tłumaczowi na taką precyzję, która $\mathrm{w}$ translacie gwarantuje spełnienie zakładanych celów komunikacyjnych, w tym i prawnych (Kielar 2010: 139). Zdaniem Autora, thumacz powinien posiadać taką wiedzę fachową, która pozwoli mu na początku procesu translacyjnego w przekładanym tekście zidentyfikować wyrażenia językowe jako terminy specjalistyczne. Następnie potrafi ustalić ich konstytutywne cechy, by na tej podstawie sprawdzić, czy w docelowym systemie prawnym istnieją podobne instytucje prawa i w jakim stopniu ustalone cechy pojęciowe pokrywają się. W końcowej fazie umie znaleźć nazwę, która te cechy reprezentuje w docelowym systemie prawnym.

$\mathrm{Z}$ analizy słowników wynika, że bardzo często brakuje w nich nazw zagregowanych, czyli takich, których zawartość semantyczna nie jest dla laika widoczna $\mathrm{w}$ ich powierzchniowej strukturze, natomiast są one kluczowe do ustalenia ekwiwalencji. Przykładem jest analizowany wcześniej termin prawny drobne naktady. Jego niewidocznymi cechami są okoliczności i podmiot, obciążony drobnymi nakładami, które dla prawnika w oczywisty implikuje ta nazwa.

Ponadto $\mathrm{W}$ procesie tłumaczenia tekstów prawnych, $\mathrm{z}$ prawniczego punktu widzenia, należy mieć na uwadze przede wszystkim materię prawną i skutek, jaki ma ona wywołać, a nie wyrażenie językowe. Znaczenie pojęcia prawnego należy interpretować $w$ ramach kontekstu systemowego i z perspektywy jego celowości. Dla prawnika pusta nazwa, czyli taka, która w translacie nie pozwala na precyzyjną identyfikację instytucji prawa, jest 
bezużyteczna. Nie jest zatem możliwe identyfikowanie pojęć bez znajomości relacji, jaka łączy je z daną nazwą. Tłumaczenie dosłowne terminologii prawnej może być zatem stosowane tylko w takich przypadkach, w których przekład w rażący sposób nie narusza zawartości informacyjnej tekstu wyjściowego.

Jak to wykazano wyżej, za pomocą kodeksu cywilnego Luizjany można ustalać w miarę precyzyjne anglojęzyczne ekwiwalencje polskich terminów z prawa cywilnego, rodzinnego oraz niektórych zakresów prawa handlowego. Ponadto może on być bardzo przydatnym narzędziem do weryfikacji terminów prawnych proponowanych przez dwujęzyczne słowniki, mimo znanych mankamentów, które wynikają $\mathrm{z}$ zastosowanych przez thumaczy LCC ewidentnych kalek terminologicznych z języka francuskiego. ${ }^{8}$

Wersja anglojęzyczna tego kodeksu ma jeszcze inną bardzo ważną zaletę. Terminologia w nim zawarta może być wykorzystana do przekładu terminów bezekwiwalentnych, szczególnie w przypadku systemów nieprzystawalnych (jak prawo stanowione i common law), tak jako to słusznie zaleca Matulewska (2005: 65). Zdaniem de Groota (2002: 34) w przypadku braku akceptowalnych ekwiwalentów w systemach prawnych wyjściowym i docelowym dopuszczalne jest stosowanie ekwiwalentów $\mathrm{z}$ innego sytemu prawnego jako neologizmów, pod warunkiem, że zaczerpnięty ekwiwalent pochodzi z sytemu prawnego państwa, w którym obowiązuje ten sam język. Podążając za jego sugestią, wydaje się, że nic nie stoi na przeszkodzie, aby w razie potrzeby do przekładu wprowadzać anglojęzyczne terminy z LCC. Terminologia zaczerpnięta z LCC nie miałaby wówczas charakteru neologizmów a quasi-neologizmów, czyli byłaby systemowo bliższa. LCC funkcjonuje bowiem obok common law w ramach jednego systemu prawnego jako jego podsystem. Tak jest w kilku stanach Ameryki i kanadyjskim Quebeku. Systemy prawne, w których obowiązują regulacje oparte na kodyfikacjach napoleońskich, stanowią ważne źródło informacji o anglojęzycznej terminologii cywilnoprawnej i w związku z tym bardzo dobrze nadają się do terminologicznych badań komparatystycznych. Zdaniem Autora należałoby prowadzić dalsze badania nad stopniem adaptacyjności terminologii m.in. LCC z innymi podsystemami na ww. terytoriach, a także nad konfrontacją terminologii LCC $\mathrm{z}$ angielskim common law.

\section{Bibliografia}

\footnotetext{
${ }^{8} \mathrm{O}$ poszukiwaniu i ustalaniu ekwiwalencji zob. Ł. Iluk: Metoda poszukiwania i ustalania terminów w różnych systemach prawnych w oparciu o akty normatywne, w druku Studia Niemcoznawcze
} 
Bocquet, Claude. 1994. Pour une méthode de traduction juridique. Prilly: CB Service.

Catford, Ian C. 1965. A Linguistic Theory of Translation. Oxford: Oxford University Press.

Groot de, Gérard-Réne. 1990. Die relative Äquivalenz juristischer Begriffe und deren Folge für mehrsprachige juristische Wörterbücher. In Translation and Meaning, part 1. Red. Marcel Thelen i Barbara LewandowskaTomaszczyk, 122-8. Maastricht: Eurotrem Maastricht.

Groot de, Gérard-Réne. 2002. Rechtsvergleichung als Kerntätigkeit bei der Übersetzung juristischer Terminologie. W Sprache und Recht. Red. Ulricke Haß-Zumker, 222-39. Berlin-New York: Walter de Gruyter.

Hannappel, Hans and Hartmut Melenk. 1990. Alltagssprache. München: Wilhelm Fink Verlag.

Iluk, Jan. 2012. Terminologia prawna i prawnicza z perspektywy interlingwalnej. Studia Linguistica 31: 7-21.

Iluk, Łukasz. 2014. Pole terminologiczne jako instrument konfrontacji leksyki prawnej dla celów leksykograficznych $i$ translacyjnych. Studia Translatorica 5: 37-48.

Kielar, Barbara. 1988. Ttumaczenie i koncepcje translatoryczne. Wrocław: Zakład Narodowy im. Ossolińskich.

Kielar, Barbara. 2007. Wiedza specjalistyczna tłumacza - na przykładzie tekstów prawnych. Języki Specjalistyczne 7. Teksty specjalistyczne jako nośniki wiedzy fachowej: 19-33.

Kielar, Barbara. 2010. Drogi i bezdroża thumaczenia tekstów prawnych. Publikacja jubileuszowa III. Lingwistyka stosowana - języki specjalistyczne - dyskurs zawodowy, 131-147. Warszawa: Katedra Języków Specjalistycznych UW.

Kielar, Barbara. 2013. Zarys translatoryki. Warszawa: Wydawnictwo Naukowe IKL@UW.

Kierzkowska, Danuta. 2002. Ttumaczenie prawnicze. Warszawa: TEPIS.

Matulewska, Aleksandra. 2005. Własność i zobowiązania w aspekcie translatorycznym polsko angielskim i angielsko-polskim. Investigationes Linguisticae 12: 62-76.

Pieńkos, Jerzy. 2003. Podstawy przekładoznawstwa. Od teorii do praktyki. Kraków: Zakamycze.

Pommer, Sieglinde. 2006. Rechtsübersetzung und Rechtsvergleichung. Translatorische Fragen zur Interdisziplinarität. Frankfurt am Main: Peter Lang. 
Sandrini, Peter. 1996. Terminologiearbeit im Recht. Deskriptiver begriffsorientierter Ansatz vom Standpunkt des Übersetzers. Wien: TermNet.

Schmidt-König, Christine. 2005. Die Problematik der Übersetzung juristischer Terminologie, Eine systematische Darstellung am Beispiel der deutschen und französischen Rechtssprache. Münster: Lit. ISBD Zitierstil.

Stolze, Radegundis. 1999. Expertenwissen des juristischen Fachübersetzers. W Übersetzen von Rechtstexten - Fachkommunikation im Spannungsfeld zwischen Rechtsordnung und Sprache. Red. Peter Sandrini, 45-62. Tübingen: Narr.

Sczaniecki, Michał. 1985. Powszechna historia państwa i prawa. Warszawa: Państwowe Wydawnictwo Naukowe.

Šarčević, Susan. 1990. Strategiebedingtes Übersetzen aus den kleineren Sprachen im Fachbereich Jura. Babel 36 (3): 155-166.

Šarčević, Susan. 1997. New Approach to legal Translation. The Hague: Kluwer Law International.

Zieliński, Lech. 2005. Kulturologiczna determinacja wyboru ekwiwalentu przez tłumacza tekstów prawnych z zakresu zobowiązań umownych. Języki Specjalistyczne 5. Teksty specjalistyczne $w$ kontekstach zawodowych i ttumaczeniach: 38-47. 